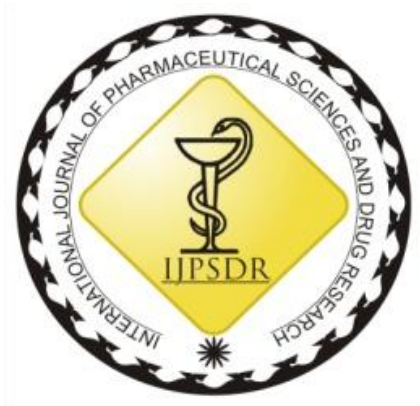

ISSN: 0975-248X

RESEARCH ARTICLE CODEN (USA): IJPSPP

$($ (c) $)$ EY-NC-SA

\title{
Pharmacological Evaluation of Antidiabetic and Diuretic Activity of Hydro-alcoholic Extract of Anogeissus latifolia Bark
}

\author{
Bhupendra Vyas*, Y. S. Sarangdevot \\ Faculty of Pharmacy, Bhupal Nobles' University, Udaipur-313001, Rajasthan, India
}

Copyright (c) 2019 Bhupendra Vyas et al. This is an open access article distributed under the terms of the Creative Commons AttributionNonCommercial-ShareAlike 4.0 International License which allows others to remix, tweak, and build upon the work non-commercially, as long as the author is credited and the new creations are licensed under the identical terms.

\begin{abstract}
The objective of the present investigation was to study the antidiabetic and diuretic potential of Anogeissus latifolia (A. latifolia) bark in experimental rats. The A. latifolia bark was extracted with hydro-alcoholic solvent by cold extraction method. Acute toxicity study was performed according to OECD 425 guidelines for hydro-alcoholic extracts of A. latifolia bark (ALBE). The dose of $150 \mathrm{mg} / \mathrm{kg}$ p.o. and $300 \mathrm{mg} / \mathrm{kg}$, p.o. of ALBE was selected for further studies. Animals were prepared diabetic by administration of alloxan $(120 \mathrm{mg} / \mathrm{kg}$, i.p.). The albino rats were divided in to five groups for oral glucose tolerance test (OGTT) and alloxan induced anti diabetic model with six animals in each group. Diabetic animals were treated with hydro-alcoholic extract of A. latifolia bark for 20 days. The blood glucose level was estimated according to standard procedures. Diuretic activity hydro-alcoholic extracts of A. latifolia was evaluated by Lipshitz method. The result shows that hydro-alcoholic extract from bark of Anogeissus latifolia $300 \mathrm{mg} / \mathrm{kg}$ (ALBE-II) shown significant hypoglycemic activity as compared to glibenclamide and diabetic group. The ALBE does not exhibit significant diuretic activity which is considered as positive marker in diabetic phenomena. Hence in present study extract of A. latifolia posses antidiabetic activity. This study may be benchmark in future to use of this drug scientifically.
\end{abstract}

Keywords: Antidiabetic, diuretic, alloxan, glibenclamide, furosemide, antioxidant, flavonoids.

DOI: 10.25004/IJPSDR.2019.110619

Int. J. Pharm. Sci. Drug Res. 2019; 11(6): 399-404

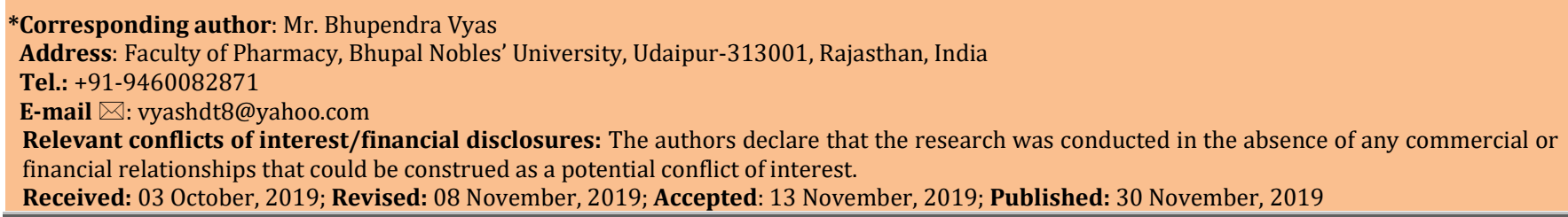

\section{INTRODUCTION}

The plants are indispensable to man for his life. Nature has provided a complete store house of remedies to cure all ailments of mankind. [1] Western medicine continues to show the influence of ancient practices. Current examples are the use of cardiac glycosides from the purple foxglove Digitalis purpurea and related plants, opiates from the opium poppy Papaver somniferum, reserpine from Rauwolfia species, and quinine from Cinchona species. ${ }^{[2]}$ More recently there has been interest in other products from traditional systems of medicine. Artemisinin is an active antimalarial compounds isolated from Artemisia annua. [3] It has been estimated by WHO that $80 \%$ of the people living in the developing countries rely upon the traditional health practices for their primary health care 
needs. [4] According to International Diabetes Federation (IDF) report, elevated blood glucose is the third uppermost risk factor for premature mortality, following high blood pressure and tobacco use globally. [5] According to World health organization (WHO) 1.5 million peoples were died because of diabetes in year 2012. Globally, in 2014 total 422 million adult were living with diabetes; the number was 108 million in 1980. [6] In 1980 the WHO also suggested to study and find out the plants which are having potential hypoglycemic activity as the modern drugs has the less safety. [7] Diabetes is a metabolic disorder characterized by chronically elevated blood glucose above the normal range. It is a chronic disease that occurs either when the pancreas does not produce enough insulin or when the body cannot effectively use the insulin it produces. ${ }^{[8]}$ In diabetes the $\beta$-cells of the pancreas decrease in number or are degranulated. The reduction in the number of $\beta$-cells corresponds to the lack of insulin. In type I Diabetes there are no $\beta$-cells while in type II Diabetes, only about one half of them are present. In some cases these cells are infiltrated with lymphocytes, suggesting an autoimmune mechanism for type I diabetes. The presence of antiislet antibodies also supports an autoimmune hypothesis in type I diabetes. The atherosclerosis occurs frequently in females than males and at an early age. In kidneys, nodular glomerulosclerosis is seen, which is the deposition of glycoprotein in wall like masses in the mesangial regions of the capillary tuft's. Diffuse glomerulosclerosis, which is the deposition of glycoprotein in mesangium, and tubular basement membrane thickening, was observed. Diabetic retinopathy is microaneurysms. Proliferative retinopathy, the formation of new blood vessels around the optic disk, occurs with long standing diabetic. Repeated hemorrhages cause scar formation that may lead to retinal detachment. The changes of hypertensive retinopathy are also seen in diabetics with hypertension. [9] There are number of remedies available for treatment of diabetes but management of it without side effect is still a big challenge. Therefore an attempt has taken to explore the Antidiabetic and diuretic potential of plant Anogeissus latifolia.

Anogeissus latifolia family Combretaceae is known as Dhurandhara, Dhava, Pishachavriksha, Nanditaru, Dhata, Sdhira, Gaura. This tree is up to $33.0 \mathrm{~m}$ in height. Leaves are elliptic- obtuse, entire, rounded at both ends. Flowers are minute, greenish yellow, in globose heads on short auxiliary peduncles. Fruits are yellowish brown or reddish brown, small, shining, beaked, winged, one seeded. Seeds wedge shaped. [10-11] It is widely distributed to Sub- Himalayan tract and Siwalik hills and in the hills throughout India, Several medicinal uses been explored in literature The roots are astringent, acrid, thermogenic and stomachic. They are useful in abdominal disorders. The bark is astringent, acrid, cooling, vulnerary, anti-inflammatory, urinary astringent, haemostatic, constipating, depurative and rejuvenating. It is useful in wounds, ulcers, inflammation, diabetes, haemorrhages, haemoptatic, constipating, depurative and rejuvenating. It is useful in wounds, ulcers, inflammation, diabetes, haemorrhages, haemoptysis, diarrhea, dysentery, haemorrhoids, skin diseases, leprosy, hepatopathy, erysipelas, ophthalmia and general debility. The leaf juice is good for otopyorrhea. The fruits are acrid, astringent, sweet, cooling and constipating. They are useful in diarrhea and dysentery. Gum is used as emulsifying agent. [12]

Anogeissus latifolia contain ellagic acid (leaf, bark, sapwood) gallotannin, corilagin, chebulic, ellagic, gallic, quinic, shikimic and m-trigallic acids [12] arabinose, fructose, galactose and rhamnose (leaves); (+) leucocyanidin, 3,3', trimethylellagic acid [13], alanine, phenylalaline (bark); myricetin, quercetin, 4-tri-0methylflavellagic acid [14] (heart wood), 3,3'-di-Omethyle ellagic acid-4'- $\beta$-D-Xyloside and 3,4,3'-triOmethylflavellagic acid-4'- $\beta$-D-glucoside [15] from stem bark. The gum, mainly the calcium salt of ghattic acid composed chiefly of L-arabinose, D-galactose, Dmanouse, D-xylose, D-galacturonic acid, galactan, pentosans, methylpentosan, riboflavin and furfural.

\section{MATERIALS AND METHODS}

\section{Drugs and chemicals}

Alloxan, glibenclamide, furosemide, Sodium chloride, potassium chloride, mercuric nitrate and diphenyl carbazone were procured from local market.

\section{Plant material selection and collection}

The bark of Anogeissus latifolia was selected based on traditional healer's claim. [16] This drug is used from time immemorial for the treatment of diabetes. The bark of A. latifolia were collected from forests of "Kewdda Ki Nal" situated on the way of Udaipur to Jaisamanad, Rajasthan and the plants was authenticated by department of Botany, University of Rajasthan, Jaipur and a voucher (RUBL20612) specimen was deposited.

\section{Preparation of extracts}

The collected bark was subjected to observation for any other mixed materials. Then the selected bark was dried in fresh air under shade. The dried bark was subjected to size reduction by dry grinder. [17] The bark powder after passing through the 60 mesh sieve subjected to hydro-alcoholic extraction. The mixture was set aside for 72 hours with occasional stirring. The obtained extracts were filtered through muslin cloth and were further concentrated by vacuum evaporator. Concentrated extract was air dried and used for further study. The suspension of hydro-alcoholic extracts was prepared by using 1\% CMC in distilled water. ${ }^{[18]}$

\section{Animals}

Albino rats (180-200 g) of either sex were used for evaluation of antidiabetic activity. The animals were housed in polypropylene cages under environmental control $\left(25 \pm 1^{\circ} \mathrm{C}\right)$ with a $12 / 12 \mathrm{~h}$ light and dark cycle 
and maintained on conventional rodent laboratory diet. Animals described as fasted were deprived of food for $16 \mathrm{~h}$ but allowed free access to water.

All animal experiments were approved by institutional animal ethical committee (Registration No. 870/ac/05/CPCSEA/Jan 05) of B. N. College of Pharmacy, Udaipur and were done as per their guidelines.

\section{Acute Toxicity Studies}

The acute toxicity of the extracts obtained from $A$. latifolia was determined by up and down procedure of Organization of Economic Cooperation and Development (OECD) guideline 425. [19] Fifteen healthy male albino rats were fasted $12 \mathrm{~h}$ prior to experiment. Rats were divided into three groups with five animals in each group. The first group serves as control group. Second and third group serves as aqueous and hydroalcoholic extract treatment groups. Extract of A. latifolia at dose of $2000 \mathrm{mg} / \mathrm{kg}$ were administered to animals. The animals were observed for seven days as animals had not shown any sign of toxicity, behavioral changes and mortality the dose increased up to $5000 \mathrm{mg} / \mathrm{kg}$. Then animals were observed up to 7 days for toxicity, behavioral changes and mortality.

\section{Induction of Experimental Diabetes [20-21]}

Alloxan monohydrate (Sigma Chemical Company, USA) was used to induce diabetes. The animals were fasted overnight and diabetes was induced by a single intra peritoneal injection of a freshly prepared solution of Alloxan $(120 \mathrm{mg} / \mathrm{kg})$ in a saline solution. The induction of diabetes was ascertained by determining fasting glucose level after 72 hours. The rats with a blood glucose level above $200 \mathrm{mg} / \mathrm{dl}$ were selected for the experiment.

\section{Oral Glucose Tolerance Test (OGTT) [22-23]}

Solution of glucose $(50 \% \mathrm{w} / \mathrm{v})$ was prepared by mixing $50 \mathrm{~g}$ of glucose in $100 \mathrm{ml}$ of distilled water and slightly warmed to dissolve the glucose. For experimental purpose, rats were kept fasting overnight but allowed free access to water. Next day morning blood samples were withdrawn and glucose level was estimated (0 min reading). Animals were then treated with respective extracts and drug solution. After $30 \mathrm{~min}$ of drug treatment, glucose solution at a dose of $2 \mathrm{~g} / \mathrm{kg}$ body weight was administered orally with the help of oral catheter. Blood samples were withdrawn after 30 , 60, 90 and $120 \mathrm{~min}$ of oral glucose load at the pre determined time interval from tail vein puncture. Glucose level was estimated by using Accutrend Alpha Glucometer. Glucose tolerance curves were drawn by plotting the concentration of glucose in blood as fraction of time. Rats were divided in five groups of six animals in each group.

Group I received 1\% CMC suspension served as control Group II received Glucose $(2000 \mathrm{mg} / \mathrm{kg}$, p.o.)

Group III received Standard reference drug Glibenclamide (10 mg/kg, p.o.)

Group IV received ALBE-I (150 mg/kg, p.o.)
Group V received ALBE-II ( $300 \mathrm{mg} / \mathrm{kg}$, p.o.)

Antidiabetic activity (Alloxan induced diabetic model) [16-17]

The selected animals were divided into five groups with six animals in each group for the study of antidiabetic activity. They were treated with the plant extracts excluding the normal and diabetic control groups. Blood samples were drawn for measuring blood glucose levels from each group on day $0,7,14$ and 21 during the study period. [24] Changes in body weight were also recorded. Groups 1 and 2 served as normal and diabetic controls. Group 3 received standard drug (glibenclamide, $10 \mathrm{mg} / \mathrm{kg}$ per day orally). ${ }^{25]}$ Groups $4 \& 5$ received the hydro-alcoholic extract at a dose of $150 \& 300 \mathrm{mg} / \mathrm{kg}$, respectively.

Group-I: Animal served as normal and received 1\% CMC suspension, p.o.

Group-II: Animals were treated with single dose of Alloxan $(120 \mathrm{mg} / \mathrm{kg}$, i.p. $)$

Group-III: Standard reference drug: Alloxan

$\mathrm{mg} / \mathrm{kg}$, i.p.) + Glibenclamide (10 mg/kg, p.o.)

Group-IV: Alloxan $(120 \mathrm{mg} / \mathrm{kg}$, i.p. $)+$ ALBE - I (150

$\mathrm{mg} / \mathrm{kg}$, p.o.)

Group-V: Alloxan $(120 \mathrm{mg} / \mathrm{kg}$, i.p $)+$ ALBE - II (300 $\mathrm{mg} / \mathrm{kg}$, p.o.)

Blood samples were collected from individual rat by orbital sinus under ether anesthesia and were analyzed by using the glucometer.

Diuretic activity ${ }^{[26-27]}$

Lipshitz method was employed for the evaluation of diuretic activity of extracts. This method is based on measurement of volume of urine, amount of sodium, potassium and chloride ions in urine of test animals, in comparison with control. This method has been proven to be a standard method and a very useful tool for screening of potential diuretics.

The animals were divided into four groups containing six animals in each group. The drugs were treated orally using saline $(25 \mathrm{ml} / \mathrm{kg}$, p.o.) as follows

Group I- Normal saline $25 \mathrm{ml} / \mathrm{kg}$ and served as control

Group II- Furosemide (100 mg/kg, body weight) and served as standard

Group III- received ALBE-I ( $150 \mathrm{mg} / \mathrm{kg}$ body wt., p.o.)

Group IV- received ALBE-II (300 mg/ kg body wt., p.o.)

After dosing, three animals per group were placed in metabolic cages provided with wire mesh bottom and a funnel specially designed to separate urine and faces. During the experimentation, the animals were neither given water nor food. Two groups of three animals each were used for individual test compound and the urine sample were collected in measuring cylinder after 5 hours of dosing. During this period, no food or water was made available to animals. The total volume of urine was collected and measured separately in both control and treated groups. The collected urine sample were analyzed for $\mathrm{Na}^{+}$and $\mathrm{K}^{+}$contents by flame photometry, while $\mathrm{Cl}^{-}$content was determined titrimetrically. 
The results are expressed as the mean \pm SEM per group, and the data were analyzed by one-way analysis of variance (ANOVA) followed by Dunnett's test as post hoc test. $P$ value $<0.05$ was considered statistically significant.

\section{RESULTS AND DISCUSSION}

Result of the acute toxicity studies suggested that the extracts obtained from bark of A. latifolia was well tolerated up to the dose of $2000 \mathrm{mg} / \mathrm{kg}$ body weight. One animal out of five died at a dose of $2.5 \mathrm{~g} / \mathrm{kg}$ body weight. A dose of 150 and $300 \mathrm{mg} / \mathrm{kg}$ body weight were selected for present studies. During the acute toxicity study, the behavioral activities were observed and were found normal.

Administration of extract obtained from A. latifolia at dose $2000 \mathrm{mg} / \mathrm{kg}$ did not produce any observable toxicity on experimental animals. The toxicity studies also suggest that the extract treated rats have no significant changes in the relative weights. The $\mathrm{LD}_{50}$ was found greater than the tested dose $(2000 \mathrm{mg} / \mathrm{kg})$ as three or more animals survived. In acute toxicity study, ALBE animals did not show any change in their behavioral pattern. No any significant difference in the body weights and food consumption was observed when compared to the vehicle treated group. Also, no gross pathological changes were seen. Thus, it was concluded that the extracts are safe at $2000 \mathrm{mg} / \mathrm{kg}$, which is consistent with Sharma et al., 2018 results. [28] Oral Glucose Tolerance Test (OGTT)
Glucose at dose of $2 \mathrm{~g} / \mathrm{kg}$ was orally administered, after the administration of different treatment. Blood glucose level was estimated at 0, 30, 60 and 120 minutes after treatment. Blood glucose level in different treated groups, after 120 minutes were found 107.18, 123.53 and $112.66 \mathrm{mg} / \mathrm{dl}$ in glibenclamide, ALBE-I and ALBEII treated group respectively. Percent increase in blood glucose level was calculated and found to be $14.83 \%$, $33.47 \%$ and $19.62 \%$ for glibenclamide, ALBE-I, ALBE-II treated group respectively. These results indicate that ALBE-II significantly tolerate the oral glucose as compared to glibenclamide treated group. Results of OGTT are given in Table 1.

Antidiabetic Activity (Alloxan induced diabetic model)

Hydro-alcoholic extract of A. latifolia produced a dose dependent hypoglycemia in alloxan-induced diabetic rats. They produced significant reduction in blood glucose with dose of 150 and $300 \mathrm{mg} / \mathrm{kg}$ body weight as compared to control. Blood glucose level was observed on $7^{\text {th }}, 14^{\text {th }}$ and $21^{\text {st }}$ days of study in alloxan treated diabetic model. The maximum reduction of blood glucose level produced by glibenclamide, ALBE-I and ALBE-II were measured as 57.48, 35.60 and 52.66\% respectively on $21^{\text {st }}$ day of study. The Values are 123.16 , 192.33 and $139.33 \mathrm{mg} / \mathrm{dl}$ respectively for glibenclamide, ALBE-I, ALBE-II. These results indicate that ALBE-II possess higher hypoglycemic activity $\left(139.33 \pm 1.333\right.$ i.e. $52.66 \%$ at $21^{\text {st }}$ day) than other extracts. Results are summarized in Table 2.

Table: 1 Effect of A. latifolia bark extracts on the blood glucose level in glucose loaded rats. (OGTT)

\begin{tabular}{|c|c|c|c|c|c|c|c|c|}
\hline \multirow[b]{2}{*}{ Group } & \multirow[b]{2}{*}{ Treatment } & \multirow{2}{*}{$\begin{array}{c}\text { Dose } \\
(\mathrm{mg} / \mathrm{kg})\end{array}$} & \multicolumn{5}{|c|}{ Blood glucose level in $\mathrm{mg} / \mathrm{dl} \pm$ S.E. } & \multirow{2}{*}{$\begin{array}{c}\text { Percent Increase } \\
\text { in blood glucose } \\
\text { level }\end{array}$} \\
\hline & & & $0 \mathrm{~min}$ & $30 \mathrm{~min}$ & $60 \mathrm{~min}$ & $90 \mathrm{~min}$ & $120 \mathrm{~min}$ & \\
\hline I & Control & $1 \% \mathrm{CMC}$ & $91.75 \pm 0.44$ & $92.46 \pm 0.53$ & $91.95 \pm 0.55$ & $90.5 \pm 0.41$ & $91.28 \pm 0.56$ & - \\
\hline II & Glucose & 2000 & $91.86 \pm 0.89$ & $155.6 \pm 0.78$ & $180.5 \pm 0.69$ & $153.2 \pm 0.71$ & $144.71 \pm 0.85$ & - \\
\hline III & Glibenclamide & 10 & $93.33 \pm 1.00$ & $132.56 \pm 0.53^{* *}$ & $141.48 \pm 0.66^{* *}$ & $124.55 \pm 0.22^{* *}$ & $107.18 \pm 0.75^{* * *}$ & $14.83 \%$ \\
\hline IV & ALBE-I & 150 & $92.55 \pm 1.14$ & $146.06 \pm 0.43$ & $154.13 \pm 0.44$ & $131.08 \pm 0.55$ & $123.53 \pm 0.49^{*}$ & $33.47 \%$ \\
\hline $\mathbf{V}$ & ALBE-II & 300 & $94.18 \pm 1.03$ & $140.85 \pm 0.64^{*}$ & $146.61 \pm 0.37^{*}$ & $128.93 \pm 0.39^{*}$ & $112.66 \pm 0.30^{* *}$ & $19.62 \%$ \\
\hline
\end{tabular}

All values are represented as Mean \pm SE $(n=6)$. P value; ${ }^{* *}<0.001,{ }^{* *}<0.01 ;^{*}<0.05$ when compared with glucose treated model. ALBE $-A$. Latifolia bark extract.

Table: 2 Effect of A. latifolia bark extracts in alloxan induced diabetic rats. (Multi days study)

\begin{tabular}{|c|c|c|c|c|c|c|c|}
\hline \multirow{2}{*}{ Group } & \multirow{2}{*}{ Treatment } & \multirow{2}{*}{$\begin{array}{c}\text { Dose } \\
(\mathrm{mg} / \mathrm{kg})\end{array}$} & \multicolumn{4}{|c|}{ Blood glucose level in $\mathrm{mg} / \mathrm{dl} \pm$ S.E. } & \multirow{2}{*}{$\begin{array}{l}\text { Percent change in } \\
\text { glucose level }\end{array}$} \\
\hline & & & Zero Day & $7^{\text {th }}$ Day & 14th Day & 21 st Day & \\
\hline I & Control & $1 \% \mathrm{CMC}$ & $84.66 \pm 1.25$ & $82.66 \pm 1.11$ & $81.83 \pm 0.65$ & $78.33 \pm 0.80$ & - \\
\hline II & Alloxan & 120 & $306.83 \pm 1.32$ & $299.33 \pm 0.84$ & $294.00 \pm 1.03$ & $291.33 \pm 0.42$ & - \\
\hline III & Glibenclamide & 10 & $289.66 \pm 3.63$ & $218.66 \pm 2.81$ & $152.66 \pm 0.84$ & $123.16 \pm 0.98$ & $57.48 \%$ \\
\hline IV & ALBE-I & 150 & $298.66 \pm 2.66$ & $284.66 \pm 1.68$ & $246.33 \pm 2.70^{* *}$ & $192.33 \pm 2.98^{* *}$ & $35.60 \%$ \\
\hline $\mathbf{V}$ & ALBE-II & 300 & $294.33 \pm 1.74$ & $245.33 \pm 2.23^{* *}$ & $165.66 \pm 1.81^{* * *}$ & $139.33 \pm 1.33^{* * *}$ & $52.66 \%$ \\
\hline
\end{tabular}

All values are represented as Mean \pm SE $(\mathrm{n}=6) .{ }^{* * *}<0.001 ; * * 0.01 ;{ }^{*}<0.05$ when compared with alloxan treated model. ALBE - A. Latifolia bark extract.

Table: 3 Effect of A. latifolia bark extracts on the body weight in alloxan induced diabetes in rats.

\begin{tabular}{|c|c|c|c|c|c|c|c|}
\hline \multirow{2}{*}{ Group } & \multirow{2}{*}{ Treatment } & \multirow{2}{*}{$\begin{array}{c}\text { Dose } \\
(\mathrm{mg} / \mathrm{kg})\end{array}$} & \multicolumn{4}{|c|}{ Body weight in gm \pm SE } & \multirow{2}{*}{$\begin{array}{l}\text { Percent change } \\
\text { in body weight }\end{array}$} \\
\hline & & & Zero Day & $7^{\text {th }}$ Day & $14^{\text {th }}$ Day & 21 ${ }^{\text {st }}$ Day & \\
\hline I & Control & $1 \% \mathrm{CMC}$ & $188 \pm 2.59$ & $185 \pm 2.11$ & $186 \pm 2.12$ & $185.33 \pm 2.04$ & - \\
\hline II & Alloxan & 120 & $193.33 \pm 2.40$ & $174 \pm 2.17$ & $155.33 \pm 1.90$ & $134.66 \pm 1.90$ & $-30.56 \%$ \\
\hline III & Glibenclamide & 10 & $188 \pm 2.58$ & $180 \pm 1.27$ & $177.66 \pm 1.74$ & $176 \pm 1.03$ & $-6.38 \%$ \\
\hline IV & ALBE-I & 150 & $189 \pm 1.98$ & $176 \pm 1.15$ & $168 \pm 2.12$ & $168.66 \pm 1.43$ & $-11.11 \%$ \\
\hline $\mathbf{V}$ & ALBE-II & 300 & $191 \pm 1.91$ & $183 \pm 1.52^{*}$ & $177 \pm 1.69^{* *}$ & $174.33 \pm 1.30^{* *}$ & $-8.90 \%$ \\
\hline
\end{tabular}

All values are represented as Mean \pm SE $(\mathrm{n}=6) .{ }^{* * *}<0.001 ;{ }^{* *}<0.01 ; *<0.05$ when compared with alloxan treated model. ALBE - A. latifolia bark extract. 
Change in body weight was noted on $7^{\text {th }}, 14^{\text {th }}$ and $21^{\text {st }}$ days of study in alloxan treated diabetic model. Percent change in body weight produced by glibenclamide, ALBE-I and ALBE-II were -6.38, -11.11 and -8.90\% respectively. Whereas alloxan produced $30.56 \%$ reduction in body weight on $21^{\text {st }}$ days. Results are presented in Table 3.

In diabetic condition, elevated blood glucose, reduction in body weight, polyuria, polydipsia and polyphagia are commonly observed. In our study, induction of diabetes by alloxan produced increase in blood glucose level, decrease in body weight and polyuria. In diabetic rats, observed reduction in body weight was possible due to catabolism of fats and protein. [29] Administration of ALBE improves body weight compared to diabetic control rats which indicates preventive effect of ALBE on degradation of structural proteins. The increase in blood glucose level after alloxan administration may be due to insulin deficiency or resistance state in diabetic rats. ALBE treatment significantly reduced blood glucose level in diabetic rats which represents reversal of insulin resistance or increasing insulin secretion possibly by regeneration of damaged pancreatic $\beta$-cells in alloxan induced diabetic rats. [30]

\section{Diuretic activity}

Hydro alcoholic extract bark of A. latifolia did not show significant diuretic effect. Volume of urine in furosemide, ALBE-I and ALBE-II treated groups were $4.12,2.76$ and $2.92 \mathrm{ml}$ respectively. These results are tabulated in Table 4 which are not statistically significant as compare to furosemide treated group. However the bark extract of A. latifolia at the dose of $300 \mathrm{mg} / \mathrm{kg}$ increased the level of $\mathrm{Na}^{+}, \mathrm{K}^{+}$and $\mathrm{Cl}^{-}$in urine of treated group. Results show significant natriuretic and chloruretic effect of bark extract of $A$. latifolia. Results are shown in Table 5.

Table: 4 Effect of A. latifolia bark extract on volume of urine in rats

\begin{tabular}{cccc}
\hline Group & Treatment & Dose $(\mathbf{m g} / \mathbf{k g})$ & Urine Volume $(\mathbf{m l})$ \\
\hline I & Control & Vehicle & $2.51 \pm 0.05$ \\
II & Furosemide & 100 & $4.12 \pm 0.24^{* * *}$ \\
III & ALBE-I & 150 & $2.76 \pm 0.62^{\mathrm{NS}}$ \\
IV & ALBE-II & 300 & $2.92 \pm 0.19^{\mathrm{NS}}$ \\
\hline
\end{tabular}

All values are represented as Mean \pm SE $(n=6)$ ALBE $-A$. latifolia bark extract

Table: 5 Effect of A. latifolia bark extract on electrolyte level in rats.

\begin{tabular}{ccccccc}
\hline Group & Treatment & Dose $(\mathbf{m g} / \mathbf{k g})$ & $\mathbf{N a}^{+}(\mathbf{m E q} / \mathbf{L})$ & $\mathbf{K}^{+}(\mathbf{m E q} / \mathbf{L})$ & $\mathbf{C l}-(\mathbf{m E q} / \mathbf{L})$ & $\mathbf{N a}^{+} / \mathbf{K}^{+} \mathbf{R a t i o}$ \\
\hline I & Control & Vehicle & $87.33 \pm 1.54$ & $60.65 \pm 0.97$ & $82.64 \pm 1.85$ & 1.43 \\
II & Furosemide & 100 & $124.00 \pm 1.42^{* *}$ & $98.65 \pm 1.67^{* *}$ & $116.32 \pm 1.52^{* * *}$ \\
III & ALBE-I & 150 & $86.96 \pm 1.52$ & $66.72 \pm 1.98$ & $93.43 \pm 1.32$ & 1.25 \\
IV & ALBE-II & 300 & $98.22 \pm 3.45^{*}$ & $72.76 \pm 1.92^{*}$ & $106.12 \pm 2.95^{* *}$ & 1.30 \\
\hline
\end{tabular}

All values are represented as mean $\pm \mathrm{SE}(\mathrm{n}=6) . P$ Value: ${ }^{* *}<0.001,{ }^{* *}<0.01 ;{ }^{*}<0.05$ when compared with control model. ALBE - A. latifolia bark extract

Some data have raised concerns about a risk of type 2 diabetes with long-term use of thiazide diuretics. The small extra risk was reported in the 1960s when relatively high doses were used. This concern is reemerging on the basis of recent trials that suggest that a greater proportion of patients have developed diabetes while taking thiazides than have developed the disorder while taking other anti-hypertensives. [31]

Thiazide-type diuretics, which include thiazide diuretics such as hydrochlorothiazide (HCTZ) and thiazide-like diuretics such as chlorthalidone (CTD) and indapamide, are a classic class of antihypertensive medications. Studies over decades have demonstrated a reduction in morbidity and mortality of cardiovascular events in patients who receive thiazide-type diuretics. [32-33] Present investigation finding supports the idea of efficiency of hydro-alcoholic extract of Anogeissus latifolia bark has significant antidiabetic activity without showing the diuretic effect.

\section{REFERENCES}

1. Kokate CK, Purohit AP, Gokhale SB. Pharmacognosy. Forty First Edn. Nirali Prakashan, Pune, 2008, p. 1.1

2. Panda H. Hand book on drugs from natural source. Asia Pacific Business Press Inc., Delhi, 2010, p. 1.

3. Klayman DL, Lin AJ, Acton N, Jhon PS, Hoch JM, Milhous WK, Theoharides, Dobek AS. Isolation of Artemisinin
(Qinghaosu) from Artemisia annua growing in the United States. J. Nat. Prod. 1984; 47(4): 715-717.

4. Austin DF, Bourne GR. In vitro cell development, Biol Plant, 1992; 33:111-13.

5. International Diabetes Federation (IDF) Diabetes Atlas-7th Edition, 2015. http://www.diabetesatlas.org/resources/2015-atlas.html

6. WHO, Definition, diagnosis and classification of diabetes mellitus and its complications. Geneva: World Health Department on Non communicable Disease Surveillance, 1999.

7. Alfiani UP, Tanti AS. Antidiabetic activity of durian (Durio zibethinus Murr.) and rambutan (Nephelium lappaceum L.) Fruit peels in alloxan diabetic rats. Procedia Food Science. 2015; 3:255-261.

8. Global report on diabetes, WHO, 2016, Publications of the World Health Organization.

9. Lehninger AL. Biochemistry. $2^{\text {nd }}$ ed., Kalyani Publishers, New Delhi, 1995, p. 720.

10. Misra RM et al. Dieback and mortality of Anogeissus latifolia Wall. in Jhansi Forest Division. Indian Journal of Forestry. 1994; 17 (2): 142-145.

11. Modgil SK, Nayithal RK. Studies on rooting response of Anogeissus latifolia wall. Range Management and Agroforestry. 1998; 19(1): 67-68.

12. Reddy $\mathrm{KK}$ et al. Isolation of gallic, chebullic \& trigallic acid from Dhava leaves, Buii. Cent. Health Res. Inst: 1962; 9:34

13. Reddy KK et al. Isolation of Naturally occurring trimethyl ether of ellagic acid from bark Anogeissus latifolia, Curr. Sci: 1962; 43(17): 544-5.

14. Reddy KRS et al. Isolation of 3, 3', 4-tri-0-methylflavellagic acid from Dhava leaves, Bull. Cent. Health Res. Inst.: 1974; 9: 34. 
Bhupendra Vyas et al. / Pharmacological Evaluation of Antidiabetic and Diuretic Activity of Anogeissus.

15. Deshpande VH, Patil AD, Rama Rao AV et al. 3, 3'-di- Omethyl ellagic acid-4'- $\beta$ D-Xyloside and 3,4,3'-triomethylflavellagic acid-4'- $\$$-Dglucoside from the Anogeissus latifolia bark. Indian J. Chem. 1976; 14: 641-643.

16. Shawl HU, Tripathi L, Bhattacharya S. Anti diabetic Plants used by Tribes in Madya Pradesh. Natural Product Radiance, 2004; 3(6): 427.

17. Nguta JM, Appiah-Opong R, Nyarko AK et al. Antimycobacterial and cytotoxic activity of selected medicinal plant extracts. Journal of Ethnopharmacology. 2016; 182:10-15.

18. Dora MB, Isabel CG, Julieta V, Fernando A, Andrea G, Jose AF. Neuropharmacological effects of the ethanolic extract of Sida acuta. Brazilian Journal of Pharmacognosy. 2016; 26:20915.

19. OECD guideline for testing of chemicals. Acute Oral Toxicity Acute Toxic Class Method (425); OECD 2008.

20. Szkudelski T, The mechanism of alloxan and strptozotocin action in $\beta$-cells of the pancreas. Physiol. Res. 2001; 50: 536546.

21. Resiraphav K, Sabu MC, Kuttan R. Hypoglycemic effect of methanol extract of Phyllanthus amarus Schum \& Thorn on alloxan induced diabetes mellitus in rats, its relation with antioxidant potential. Ind. J. Exp. Biol. 2002; 40: 905-909.

22. Bonner-Weir S, Morphological evidence of pancreatic polarity of beta cells within islets of langerhans. Diabetes 1988;37:616-21

23. World Health Organization and International Diabetes Federation, Definition, diagnosis and classification of diabetes mellitus and its complications. Geneva, Switzerland: 1999. World Health Organization.
24. Nagappa AN, Thakurdesai PA, Rao NV, Singh J. Antidiabetic activity of Terminalia catappa Linn fruits. J Ethnopharmacol. 2003;88(1):45-50.

25. Ragavan B, Krishnakumari S. Antidiabetic effect of $T$. arjuna bark extract in alloxan induced diabetic rats. Indian J Clin Biochem. 2006;21(2):123-128.

26. Lipschitz WL, Hadidan Z and Kepsar A, J. Pharmacol. Exp. Ther. 1943; 73-97.

27. Kaushal R, Tripathi RM, Veerajaneyalu A, Krishnamurthy A, Thaper GS, Verma RK, Studies on diuretic effect of ST-93: A clonidine analog. Ind. J. Pharmacol. 1993;25(2):25-98.

28. Sharma VC, Kaushik A, Evaluation of anticonvulsant effects of stem bark of Anogeissus latifolia (Roxb.) in mice Journal of Applied Pharmaceutical Science 2018 Vol. 8(11), 069-074.

29. Veeramani C, Pushpavalli G, Pugalendi KV. Antihyperglycaemic effect of Cardiospermum halicacabum Linn. leaf extract on streptozotocin induced diabetic rats. J Appl Biomed 2007; 6(1): 19-26.

30. Sezik E, Aslan M, Yesilada E, Ito S. Hypoglycaemic activity of Gentiana olivieri and isolation of the active constituent through bioassay-directed fractionation techniques. Life Sci 2005; 76(11): 1223-1238

31. Rashidi A. Risk of Diabetes in Patients Taking Thiazide Diuretics. Mayo Clinic Proceedings, 2006;81(12):1637-1638.

32. Mortality after 10.5 years for hypertensive participants in the multiple risk factor intervention trial. Circulation. 1990;82:1616-1618

33. Brown MJ, Palmer CR, Castaigne A, et al., Morbidity and mortality in patients randomized to double-blind treatment with a long-acting calcium-channel blocker or diuretic in the International Nifedipine GITS study: Intervention as a Goal in Hypertension Treatment (INSIGHT). Lancet 2000; 356:366372.

HOW TO CITE THIS ARTICLE: Vyas B, Sarangdevot YS. Pharmacological Evaluation of Antidiabetic and Diuretic Activity of Hydro-alcoholic Extract of Anogeissus latifolia Bark. Int. J. Pharm. Sci. Drug Res. 2019; 11(6): 399-404. DOI: 10.25004/IJPSDR.2019.110619 